\title{
Zakrzepowe zapalenie żył głębokich kończyny dolnej u młodego mężczyzny powikłane skrzepliną prawego przedsionka przechodzącą przez otwór owalny do lewego przedsionka i zatorowością płucną
}

\author{
Deep vein thrombosis of the lower limb in a young man complicated \\ by the right atrium thrombus passing through the foramen ovale \\ into the left atrium and pulmonary embolism
}

\author{
Joanna Relewicz ${ }^{1}$, Dariusz Dąbrowski ${ }^{2}$, Rafał Kleczyk ${ }^{1}$, Maciej Guziński ${ }^{3}$, \\ Monika Przewłocka-Kosmala ${ }^{1}$ \\ ${ }^{1}$ Katedra i Klinika Kardiologii Uniwersytetu Medycznego im. Piastów Śląskich we Wrocławiu \\ ${ }^{2}$ Wojewódzki Szpital Specjalistyczny w Legnicy \\ ${ }^{3}$ Katedra Radiologii Uniwersytetu Medycznego im. Piastów Śląskich we Wrocławiu
}

\section{Streszczenie}

Obecność ruchomej skrzepliny przechodzącej z prawego przedsionka przez drożny otwór owalny do lewego przedsionka jest zjawiskiem rzadko opisywanym w światowej literaturze medycznej, stanowi natomiast stan bezpośredniego zagrożenia życia wynikający z dużego ryzyka masywnej zatorowości systemowej. Wybór odpowiedniego sposobu leczenia stanowi poważne wyzwanie w tego typu przypadkach, a skąpy materiał kliniczny uniemożliwia przeprowadzenie badań zakończonych wyciągnięciem konstruktywnych wniosków. W niniejszej pracy zaprezentowano przypadek 28-letniego mężczyzny z zakrzepowym zapaleniem żył głębokich podudzia lewego powikłanym zatorowością płucną, ze stwierdzoną w przezklatkowym badaniu echokardiograficznym ruchomą skrzepliną przechodzącą z prawego do lewego przedsionka przez drożny otwór owalny, leczoną skutecznie chirurgiczną embolektomią z zaszyciem otworu owalnego.

Słowa kluczowe: zakrzepowe zapalenie żył głębokich, zakrzep przechodzący przez otwór owalny, zatorowość płucna

Folia Cardiologica 2016; 11, 5: 443-446

\section{Wstęp}

Najczęstszą przyczynę zatorowości płucnej (PE, pulmonary embolism) stanowi skrzeplina przemieszczająca się z układu żył głębokich kończyn dolnych lub żył miednicy mniejszej przez żyłę główną dolną i jamy prawego serca do płucnego układu tętniczego. Obecność skrzepliny w jamach prawego serca stwierdza się dość rzadko, jednak jej występowanie znacznie pogarsza rokowanie u pacjentów z PE. Dodatkowym czynnikiem obciążającym w takiej sytuacji bywa drożny otwór owalny, który obserwuje się u 27\% populacji ogólnej [1], umożliwiający w przypadku podwyższenia ciśnienia w prawych jamach serca migrację materiału zatorowego do układu tętnic systemowych z następową zatorowością paradoksalną, w tym z najcięższą jej formą - zatorowością w obrębie ośrodkowego układu nerwowego. W prezentowanej pracy przedstawiono przypadek młodego pacjenta z żylną chorobą zakrzepowo-zatorową

Adres do korespondencji: dr hab. n. med. Monika Przewłocka-Kosmala, Katedra i Klinika Kardiologii, Uniwersytet Medyczny im. Piastów Śląskich, ul. Borowska 213, 50-556 Wrocław, tel. 7173642 41, faks 7173642 09, e-mail: monika.przewlocka-kosmala@umed.wroc.pl 
ze stwierdzoną skrzepliną przechodzącą z prawego do lewego przedsionka.

\section{Opis przypadku}

Mężczyzna w wieku 28 lat, otyły (wskaźnik masy ciała [BMI, body mass index] $31 \mathrm{~kg} / \mathrm{m}^{2}$ ) z rozpoznanym nadciśnieniem tętniczym i upośledzoną tolerancją glukozy, dotychczas nieleczący się i prowadzący siedzący tryb życia (praca przy komputerze) w maju 2013 roku odczuł pogorszenie wydolności wysiłkowej (duszność przy wchodzeniu po schodach) oraz zaobserwował wystąpienie obrzęku lewej kończyny dolnej. Pacjent objawy te bagatelizował przez 3 tygodnie. Gdy doszło u niego do nagłego pogorszenia stanu zdrowia z pojawieniem się duszności spoczynkowej uniemożliwiającej jakąkolwiek aktywność fizyczną, zgłosił się do poradni kardiologicznej. Na podstawie badania podmiotowego, przedmiotowego oraz wykazanego w przezklatkowym badaniu echokardiograficznym powiększenia prawych jam serca stwierdzono podejrzenie PE i skierowano go na szpitalny oddział ratunkowy uniwersyteckiego szpitala klinicznego.

Wykonane przy przyjęciu badania wykazały podwyższone stężenie D-dimerów (5,96 mg/ml; norma: 0,0-0,5), troponiny $(0,118 \mathrm{ng} / \mathrm{ml}$; norma: 0,0-0,028), hipokapnię krwi tętniczej $\left(\mathrm{pCO}_{2} 25 \mathrm{~mm} \mathrm{Hg}, \mathrm{pO}_{2} 104 \mathrm{~mm} \mathrm{Hg}, \mathrm{pH}\right.$ 7,49). W zapisie EKG zarejestrowano tachykardię zatokową 107/ /min, dekstrogram, blok prawej odnogi pęczka Hisa, ujemne załamki T w odprowadzeniach V1-V5. W obrazie wielorzędowej tomografii komputerowej tętnic płucnych stwierdzono liczne rozsiane zatory w obrębie tętnic płatowych, segmentowych i subsegmentowych z zatorem typu jeździec na poziomie tętnic płatowych (ryc. 1). W USG żył kończyn dolnych potwierdzono obecność materiału zakrzepowego w obrębie żyły podkolanowej lewej sięgającego żyły udowej. Pacjenta przyjęto do Kliniki Kardiologii z potwierdzonym rozpoznaniem PE w przebiegu zakrzepicy żył głębokich kończyny dolnej lewej i włączono leczenie dożylnym wlewem heparyny niefrakcjonowanej pod kontrolą czasu częściowej tromboplastyny po aktywacji (APTT, activated partial thromboplastin time), uzyskując szybką poprawę stanu klinicznego.

W kolejnym dniu hospitalizacji przy dobrym samopoczuciu chorego wykonano przezklatkowe badanie echokardiograficzne, które wykazało przechodzącą przez otwór owalny balotującą, podłużną skrzeplinę o wymiarach $10 \times 1 \mathrm{~cm}$ obecną zarówno w prawym, jak i w lewym przedsionku, okresowo także przedostającą się przez zastawkę trójdzielną do prawej komory, powiększenie (<50 mm w projekcji koniuszkowej 4-jamowej) i dysfunkcję skurczową prawej komory (pomiar wychylenia skurczowego pierścienia trójdzielnego [TAPSE, tricuspid annular plane systolic excursion] $15 \mathrm{~mm}$ ), nadciśnienie płucne $z$ gradientem prawa komora-prawy przedsionek (RA, right atrium) $55 \mathrm{~mm} \mathrm{Hg}$, zazębienie śródskurczowe na

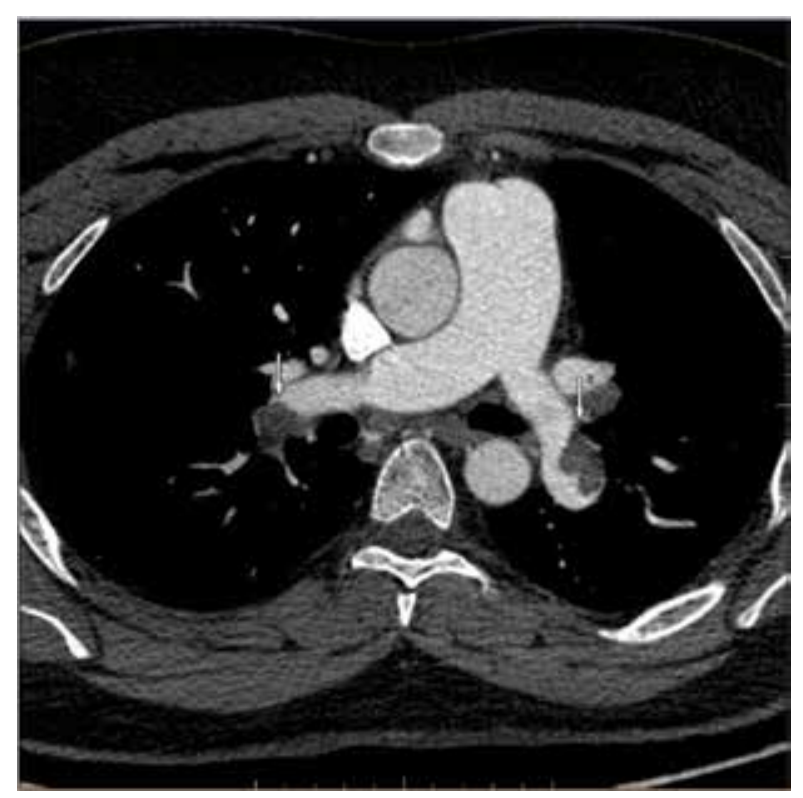

Rycina 1. Obraz angiografii komputerowej płuc uwidaczniający zatory w prawej i lewej tętnicy płucnej (białe strzałki)

ramieniu wstępującym spektrum wypływu z prawej komory ze skróconym do 55 ms czasem przyspieszenia wyrzutu krwi przez zastawkę pnia płucnego świadczące o zwiększonej impedancji płucnej, cechy przeciążenia ciśnieniowego prawej komory w postaci objawu litery D w trakcie skurczu (ryc. 2-4). Podjęto wówczas decyzję o pilnym leczeniu kardiochirurgicznym, które przeprowadzono w ciągu pierwszej doby od zgłoszenia się pacjenta do szpitala - usunięto skrzeplinę z przedsionków, odessano drobne skrzepliny z tętnic płucnych oraz zaszyto otwór owalny.

Po zabiegu kontynuowano wlew heparyny, a następnie włączono doustną antykoagulację na 6 miesięcy. W dalszym postępowaniu wykluczono potencjalne przyczyny choroby zakrzepowo-zatorowej, między innymi proces rozrostowy, stan zapalny, trombofilię, układowe choroby tkanki łącznej. Pacjenta wypisano do domu w 20. dobie hospitalizacji w stanie dobrym.

Chociaż PE może wystąpić u osób bez uchwytnych czynników predysponujących, to najczęściej u pacjentów z PE stwierdza się obecność jednego czynnika lub kilku (wtórna $P E)$. Odsetek chorych z idiopatyczną lub niesprowokowaną PE w Międzynarodowym Rejestrze Zatorowości Płucnej (ICOPER, International Cooperative Pulmonary Embolism Registry) wynosi około 20\% [2]. U przedstawionego młodego pacjenta z submasywną PE z ewidentnych czynników ryzyka stwierdzono jedynie otyłość. Wykazano, że o ile otyłość zwiększa 2,5-krotnie ryzyko zakrzepicy żył głębokich w populacji ogólnej, a względne ryzyko PE 2,21-krotnie, to w populacji osób otyłych przed 40. rokiem życia względne ryzyko zakrzepicy żył głębokich i PE jest dużo wyższe i wynosi - odpowiednio - 5,2 i 5,19 [3]. 


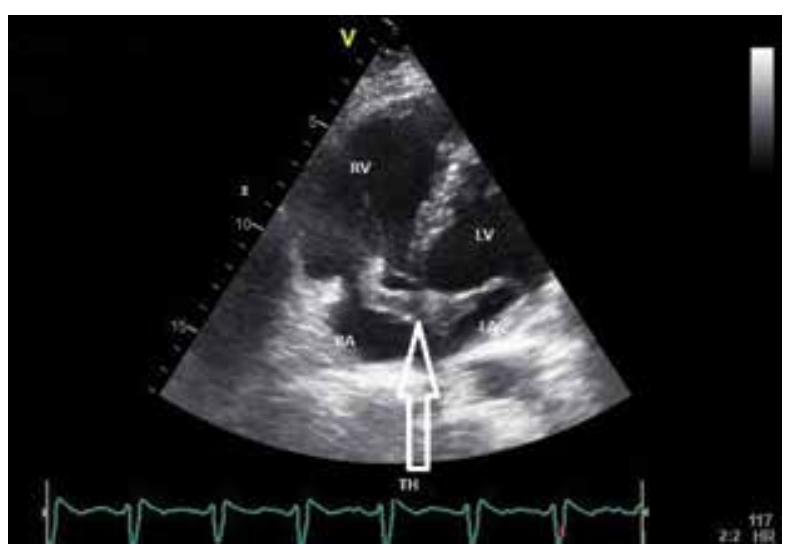

Rycina 2. Przezklatkowe badanie echokardiograficzne w projekcji koniuszkowej 4-jamowej; RV (right ventricle) - prawa komora; RA (right atrium) - prawy przedsionek; LV (left ventricle) - lewa komora; LA (left atrium) - lewy przedsionek; TH (thrombus) - skrzeplina

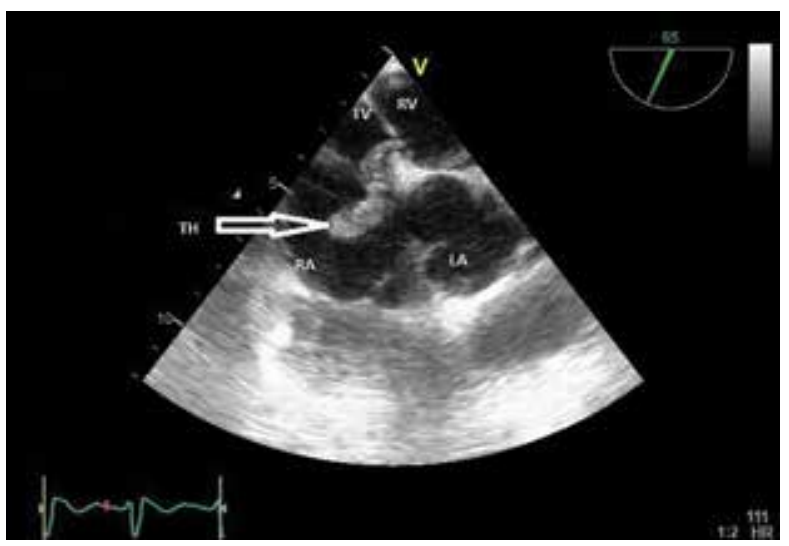

Rycina 3. Przezprzełykowe badanie echokardiograficzne; RV (right ventricle) - prawa komora; RA (right atrium) - prawy przedsionek; LA (left atrium) - lewy przedsionek; TV (tricuspid valve) - zastawka trójdzielna; TH (thrombus) - skrzeplina

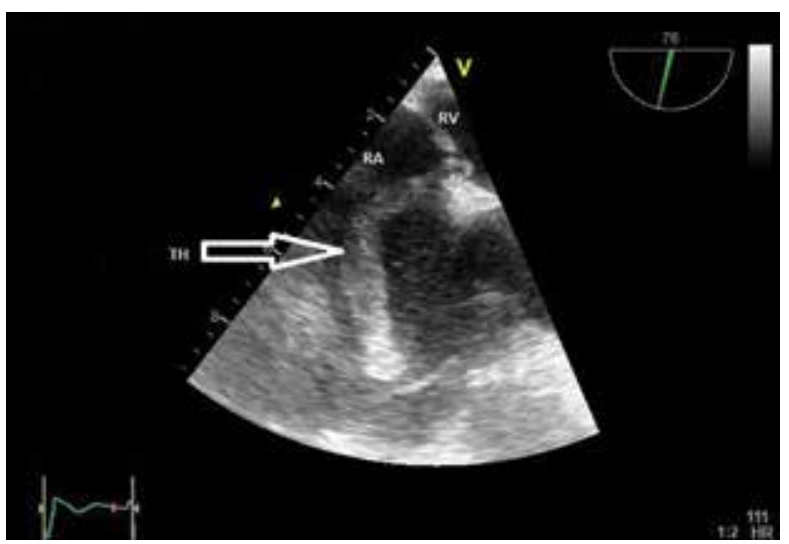

Rycina 4. Przezprzełykowe badanie echokardiograficzne; RV (right ventricle) - prawa komora; RA (right atrium) - prawy przedsionek; TH (thrombus) - skrzeplina
Obecność skrzeplin w jamach prawego serca jest rozpoznawana u około $4 \%$ pacjentów z ostrą PE. W nawiązaniu do wytycznych Europejskiego Towarzystwa Kardiologicznego wykazanie skrzepliny tego typu nakłada konieczność wdrożenia natychmiastowego leczenia bez konieczności dalszej diagnostyki [4]. Spośród trzech sposobów leczenia obejmujących: trombolizę, heparynizację lub chirurgiczną embolektomię, w przypadku skrzeplin typu „jeździec” w obrębie otworu owalnego, obarczonych śmiertelnością wewnątrzszpitalną sięgającą 45\% [5], preferowana jest embolektomia. Umożliwia ona usunięcie całości materiału zakrzepowo-zatorowego z jam serca oraz dużej części z tętniczego łożyska płucnego, a także zaszycie drożnego połączenia międzyprzedsionkowego. W literaturze światowej jest opisywanych zaledwie kilkadziesiąt przypadków pacjentów z PE i obecną skrzepliną przechodzącą z prawego do lewego przedsionka przez otwór owalny. Chorzy ci byli leczeni zarówno zachowawczo, jak i chirurgicznie. Jeśli wcześniej wystąpiły zatory paradoksalne w zakresie ośrodkowego układu nerwowego (czasami bezobjawowe) co jest zjawiskiem dość częstym w tego typu przypadkach - zastosowanie leczenia trombolitycznego niesie ze sobą bardzo duże ryzyko ukrwotocznienia ogniska zawałowego. W wyniku trombolizy może także dojść do rozkawałkowania skrzepliny w obrębie lewego przedsionka i następowej obwodowej zatorowości systemowej. Przeprowadzona przez Myersa i wsp. [6] analiza sposobów leczenia pacjentów z zatorowością paradoksalną wykazała ewidentną przewage chirurgicznej embolektomii z zaszyciem otworu owalnego w porównaniu z leczeniem trombolitycznym lub jedynie antykoagulacją. Podejście chirurgiczne wiązało się z redukcją 30-dniowej śmiertelności i zatorowości systemowej (iloraz szans [OR, odds ratio] 0,26; $p=$ $=0,001$ ) w porównaniu z samą antykoagulacją, podczas gdy w przypadku trombolizy uzyskano nieistotny trend w kierunku zwiększenia zatorowości obwodowej i 30-dniowej śmiertelności [6].

Zastosowanie heparyny u chorych z PE na tle zakrzepicy żyInej może także doprowadzić do mobilizacji fragmentów zakrzepu z układu żył głębokich i jego migracji do jam prawego serca. W przypadku omawianego pacjenta do pierwszego incydentu PE doszło najprawdopodobniej już około 3 tygodnie przed hospitalizacją, a powodem wdrożenia diagnostyki i leczenia była eskalacja choroby. Warunki te sprzyjały przetrwałemu podwyższeniu ciśnienia w krążeniu płucnym i prawych jamach serca, a kilkugodzinne leczenie heparyną mogło sprowokować przemieszczenie się fragmentów zakrzepu do prawego przedsionka i przez otwór owalny (pod wpływem wysokiego ciśnienia w prawym przedsionku) do lewego przedsionka. Nie można jednak wykluczyć, że do uwięźnięcia zakrzepu w otworze owalnym doszło jeszcze przed zastosowaniem heparyny, co mogło zostać przeoczone w wykonanym ambulatoryjnie badaniu echokardiograficznym. Mimo że aktualne rekomendacje 
towarzystw kardiologicznych nie uznają echokardiografii za badanie pierwszoplanowe u stabilnych hemodynamicznie pacjentów diagnozowanych z powodu podejrzenia PE ze względu na niewystarczającą czułość i swoistość tej tech- niki w rozpoznawaniu PE, to jednak wczesne wykonywanie badania echokardiograficznego, a także jego powtarzanie w okresie okołoincydentowym mogą zasadniczo zmienić sposób skutecznego leczenia pacjentów z PE.

\section{Abstract}

Mobile biatrial thrombus entrapped in a patent foramen ovale is a very rare condition associated with an increased risk of fatal complications due to a high prevalence of paradoxical embolism. Given the limited number of cases reported so far, recommending the most favorable treatment modality is difficult, as it cannot be supported by relevant clinical data. In our paper, we present a case of 28-year-old male patient with deep vein thrombosis of the left lower limb complicated by pulmonary embolism, with mobile thrombus in transit from the right to the left atrium through the patent foramen ovale, successfully treated with surgical embolectomy and closure of interatrial communication.

Key words: deep vein thrombosis, thrombus passing through the foramen ovale, pulmonary embolism

Folia Cardiologica 2016; 11, 5: 443-446

\section{Piśmiennictwo}

1. Nguyen D.Q., Das G.S., Grubbs B.C. i wsp. Transcatheter closure of patent foramen ovale for hypoxemia during left ventricular assist device support. J. Heart Lung Transplant. 1999; 18: 1021-1023.

2. Goldhaber S.Z., Visani L., De Rosa M. Acute pulmonary embolism: clinical outcomes in the International Cooperative Pulmonary Embolism Registry (ICOPER). Lancet 1999; 353: 1386-1389.

3. Stein P.D., Beemath A., Olson R.E. Obesity as a risk factor in venous thromboembolism. Am. J. Med. 2005; 118: 978-980.
4. Torbicki A., Perrier A., Konstantinides S. i wsp.; ESC Committee for Practice Guidelines (CPG). Guidelines on the diagnosis and management of acute pulmonary embolism: the Task Force for the Diagnosis and Management of Acute Pulmonary Embolism of the European Society of Cardiology (ESC). Eur. Heart J. 2008; 29: 2276-2315.

5. Rose P.S., Punjabi N.M., Pearse D.B. Treatment of right heart thromboemboli. Chest 2002; 121: 806-814.

6. Myers P.O., Bounameaux H., Panos A. i wsp. Impending paradoxical embolism: systematic review of prognostic factors and treatment. Chest 2010; 137: 164-170. 